\title{
Endonasal Endoscopic Skull Base Multilayer Reconstruction Surgery with Nasal Pedicled Mucosal Flap to Manage High Flow CSF Leakage
}

\author{
Yüksek Akışı BOS Sızıntısınun Tedavi Etmek için Nazal Pediküllü \\ Mukozal Fleple Endonazal Endoskopik Kafatası Tabanı Çok Tabakalı \\ Rekonstrüksiyon Cerrabisi
}

\author{
Wang XUEJIAN, Hu FAN, Zhang XIAOBIAO, Yu YONG, Gu YE, Xie TAO, Ge JUNQI \\ Fudan University, Zhongshan Hospital, Department of Neurosurgery, Shanghai, China,
}

Corresponding Author: Zhang XIAOBIAO / E-mail: 6841441@163.com

\begin{abstract}
AIM: Multilayer reconstruction of skull base using nasal pedicled mucosal flap has been widely accepted as a standard method for repairing high flow cerebrospinal fluid [CSF] leakage. In this study, we analyzed our outcome and summarized several valuable operation experiences from this technique.

MATERIAL and METHODS: This study included 20 consecutive patients who underwent endoscopic endonasal multilayer reconstruction using a nasal pedicled mucosal flap to repair high flow CSF leakage and were available for follow-up.

RESULTS: In this series, all cases encountered intraoperative high-flow CSF leakage, including 11 (55\%) patients with opening of third ventricles (TV) and $9(45 \%)$ patients with wide opening of cistern (CS). After endoscopic endonasal multilayer reconstruction with nasal pedicled mucosal flap, 3 patients (15.0\%) encountered CSF leakage in the early postoperative period but were successfully repaired; 2 patients (10.0\%) encountered late postoperative CSF leakage. In the TV group, the ratio of CSF leakage was $18.2 \%(2 / 11)$; while the incidence of CSF leakage was $11.1 \%$ (1/9) in the CS group. One patient developed meningitis due to CSF leakage four month after surgery, then gave up treatment and died. CONCLUSION: Multilayer reconstruction with nasal pedicled flap seems to be useful and reliable for the treatment of ventral skull base defects using endoscopic endonasal approach.
\end{abstract}

KEYWORDS: Endoscopic, Pedicled mucosal flap, Multilayer reconstruction, High-flow CSF leakage

ÖZ

AMAÇ: Nazal pediküllü mukozal flep kullanarak kafatası tabanının çok tabakalı rekonstrüksiyonu, yüksek akışı beyin omurilik sıvısı sızıntısını tamir etmek için standart bir yöntem olarak yaygın olarak kabul edilmiştir. Bu çalışmada bu teknikle sonuçlarımızı analiz ettik ve ameliyatlarımızdan elde ettiğimiz çeşitli değerli deneyimlerimizi özetledik.

YÖNTEM ve GEREÇLER: Bu çalışmaya yüksek akışı BOS sızıntısını tamir etmek için nazal pediküllü mukozal flep kullanılarak endoskopik endonazal çok tabakalı rekonstrüksiyon yapılan ve daha sonra takibi yapılabilen arka arkaya 20 hasta dahil edildi.

BULGULAR: Bu seride tüm vakalarda yüksek akışı BOS sızıntısı vardı ve bunlar arasında üçüncü ventrikül açıklığı olan 11 (\%55) hasta ve geniş sistern açıklığı olan 9 (\%45) hasta vardı. Nazal pediküllü mukozal fleple endoskopik endonazal çok tabakalı rekonstrüksiyon sonrasında, 3 hastada $(\% 15,0)$ erken postoperatif dönemde BOS sızıntısı oldu ama başarıyla tamir edildi; 2 hastada $(\% 10,0)$ geç postoperatif BOS sızıntısı oldu. Üçüncü ventrikül açıklığı grubunda BOS sızıntısı insidansı \%18,2 (2/11) iken geniş sistern açıklığı grubunda BOS sızıntısı insidansı \%11,1 (1/9) bulundu. Bir hastada ameliyattan 4 ay sonra BOS sızıntısı nedeniyle menenjit gelişti ve hasta tedaviyi uygulamayıp öldü.

SONUÇ: Nazal pediküllü fleple çok tabakalı rekonstrüksiyon, endoskopik endonazal yaklaşım kullanılarak ventral kafatası tabanı defektlerinin tedavisinde faydalı ve güvenilir görünmektedir.

ANAHTAR SÖZCÜKLER: Endoskopik, Pediküllü mukozal flep, Çok tabakalı rekonstrüksiyon, Yüksek akışlı BOS sızıntıSı 


\section{INTRODUCTION}

Over the past decade, the development of endoscopic neurosurgical technique and increasing neuroanatomic knowledge have resulted in significant improvements in neurosurgery. The endoscopic endonasal approach has been widely used, especially in the reconstruction of the anterior, middle, clival, and parasellar cranial base after the expanded endonasal approach (EEA) $(16,19,20)$. However, complications (CSF leakage, pneumocephalus, etc,) after surgery are still a big challenge and hindrance for the application of EEA $(7,13,21)$. Reconstruction by pedicled nasal mucosal flap has been proposed and the efficacy of reconstruction is now significantly improved and the incidence of postoperative CSF leakage is reduced to less than $5 \%$ in late period $(14,23)$. From October 2009 to March 2011, 20 consecutive patients underwent endoscopic endonasal multilayer reconstruction of the skull base with pedicled nasal mucosal flap and were available for follow-up.

\section{PATIENTS and METHODS}

\section{General Information}

This study consisted of 20 patients ( 13 men and 7 women; mean age 45.5 years, range $14-67$ years).

\section{Clinical Manifestation}

16 of 20 patients showed impaired vision, 8 patients had hemianopsia, 6 patients had headache, 3 patients presented with nausea and vomiting, 2 patients had oculomotor paralysis, 2 patients had hypopituitarism, 2 patients had polydipsia and polyuria, and 1 patient presented with amenorrhea and galactorrhea.

\section{Preoperative Examination}

All patients had complete clinical assessment. Endocrine function evaluation, examination of the visual field and visual acuity, radiological evaluation (magnetic resonance imaging [MRI] with contrast enhancement and three-dimensional magnetization-prepared rapid gradient-echo imaging [3DMPRGE], computed tomography [CT] scan, computed tomography angiogram [CTA]) were performed prior to surgery.

\section{Flap Making}

The mucosal flap was harvested from either one or both sides of the nasal septum while the right nasal septal mucosal flap was chosen as the first choice. A nasal septal pedicled flap was made according to previous methods $(14,17)$. A middle turbinate pedicled flap was made according to the method described by Prevedello et al. (Figure 1A-I) (6). After harvest, the nasal pedicled flap was stored in the nasopharynx until the extirpative phase of the surgery.

\section{Reconstruction}

During reconstruction, a collagen matrix was placed as an inlay subdural graft, while an additional fascia lata or abdominal free fat could be used as an onlay. The gasket seal technique was used in 2 cases. The mucosal flap can be applied directly to the fascia lata or abdominal free fat. Fibrin glue was used to fix the flap and nasal packing with a balloon of 12-French Foley catheter or an iodoform gauze was inserted to compress the mucosal flap against the defect. Then a lumbar spinal drain was placed, which was decided by the experienced doctors according to the possibility of intraor post-operative CSF leakage.

\section{Follow-up}

Postoperative endocrine evaluations were performed in all patients. CT and MRI were performed 1, 3, 6, and 12 months after surgery.

\section{RESULTS}

In this series, all 20 cases were verified by a pathologist after surgery. There were 7 patients with craniopharyngiomas, (Figure 2A-F) 4 patients with pituitary macroadenomas, 4 patients with clivil chordomas, 3 patients with meningiomas, 1 patient with cavernous hemangioma, and 1 patient with supersellar hemangioblastoma. Most patients were placed an external lumbar drain (ELD) postoperatively, and the packing matter was removed after 5 days. 3 patients encountered CSF leakage in the early postoperative period, and were successfully repaired by further surgery. 2 patients encountered CSF leakage in the late postoperative period (Figure 3A-C). During the intraoperative period, the incidence of opening third ventricle was $55.0 \%(11 / 20)$, and the ratio of CSF leakage was $18.2 \%(2 / 11)$ after surgery. The incidence of not opening third ventricle was $45.0 \%(9 / 20)$, while the incidence of CSF leakage was $11.1 \%(1 / 9)$. The incidence of early postoperative CSF leakage was $15.0 \%(3 / 20)$; and the incidence of late period CSF leakage was $10.0 \%(2 / 20)$. Based on the information from follow-up nasal endoscopy and MRI, the endoscopic surgery of skull base reconstruction had good results. Of the two cases with late CSF leakage, one chordoma patient was treated by Gamma Knife four months after surgery, developed meningitis due to CSF leakage, and then gave up treatment and died. The other late CSF leakage patient was repaired well, and no other complications related to the surgery or the closure technique appeared in this case during the follow-up period.

\section{DISCUSSION}

Since the neuroendoscope is applied, especially after EEA, the incidence of complications, such as CSF leakage, infection and encephalocele formation, is high. Carrabba et al. (2) reported that the incidence of CSF leakage was $24 \%$ after EEA. Therefore, the reconstruction of skull base defect is of paramount importance to prevent CSF leakage after endoscopic endonasal surgery $(9,11)$. A pedicled mucosal flap is one of the major advancements in endoscopic endonasal skull base reconstruction, which is regarded by most authors as the best method to repair a defect of the skull base $(11,14,15,21,23)$.

Here we used a multilayer technique for the reconstruction of skull base defect using a nasal pedicled mucosal flap in this series. We conclude that: (1) Autologous mucosal flap 
is homology, no host-tissue reaction. Vascularized tissue promotes fast and complete healing, and can achieve histological and anatomical repair. A pedicled nasal mucosal flap is costless, malleable, safe, and easy to obtain in the same field of surgery without inducing side effects or complications. Early in 2006, Hadad et al. $(1,14,23)$ suggested to reconstruct the defect of anterior skull base with a nasal septal pedicled mucosal flap. This technique helped to reduce the incidence postoperative CSF leakage to less than $5 \%$, so it was called Hadad-Bassagasteguy flap (HBF) and became one of the standard reconstruction styles $(12,14,17,18,21)$. (2) During surgery, some surgeons preferred to use multilayer reconstruction to ensure successful repair $(3,25)$. Ceylan et al.(4) used multilayer skull base reconstruction to markedly reduce the incidence of CSF leakage. We believe that even if the mucosal flap technique is used, it still needs a multilayer reconstruction. A mucosal flap can accelerate wound healing and restore anatomical structures, but it still needs multilayer reconstruction to get support, remain fixed, and reduce the effect of cerebrospinal fluid. Hadad (14) and El-Banhawy
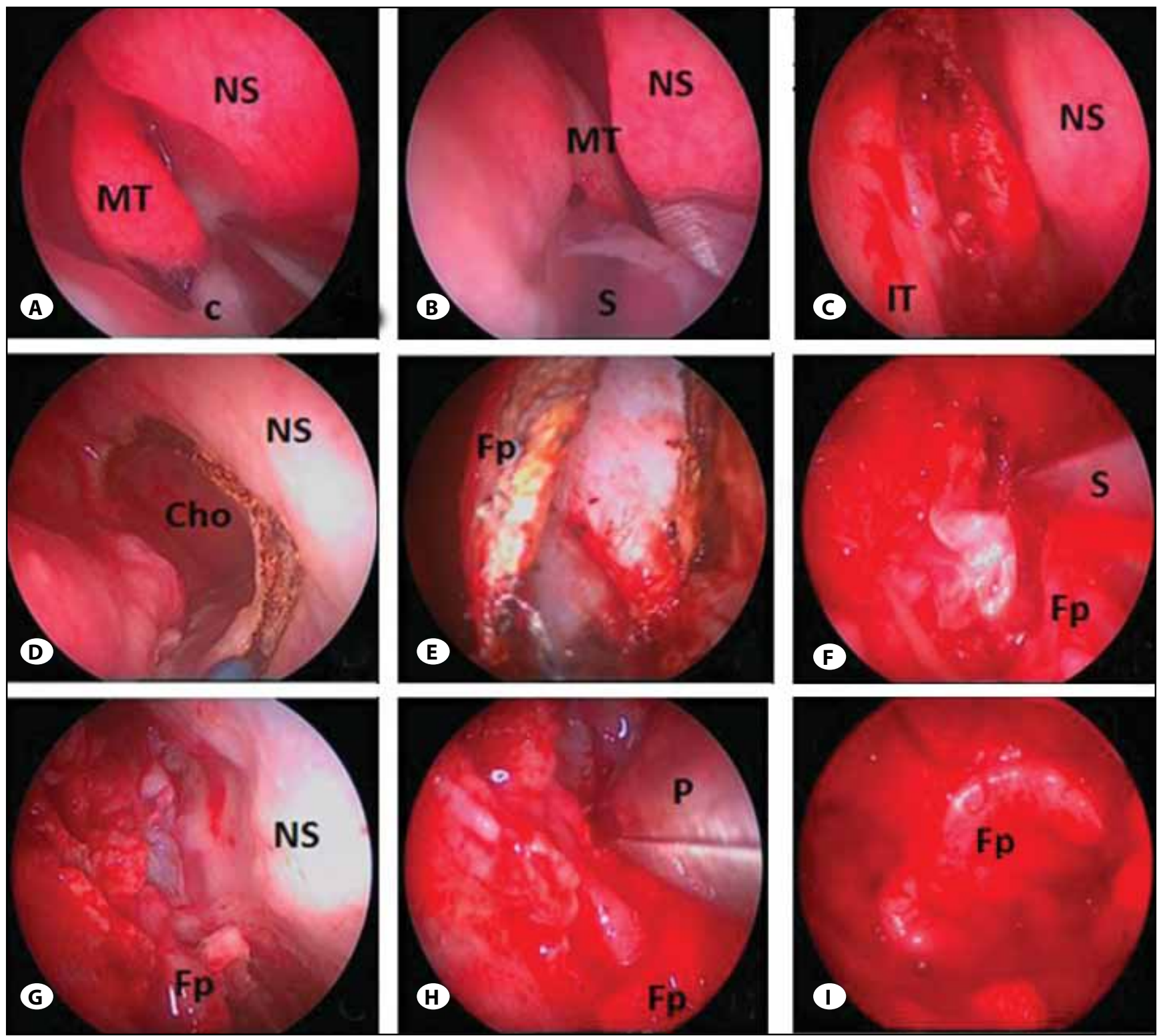

Figure 1: A-I: Procedure of making and using a mucosal flap: A) nasal mucosa is contracted; B) the middle turbinate is cut by scissors; C) the middle turbinate is removed; D) the middle turbinate mucosa is cut by a monopolar coagulation and the cut is beginning from the upper edge of the choanae; E) vertical incision is made at the front of the mucosal flap, and then elevates the mucosa; F) the top incision of mucosal flap is cut open by scissors, and the cut was 1 to $2 \mathrm{~cm}$ below the most superior aspect of the septum (this preserves the olfactory epithelium); G) the nasoseptal flap is "stored" at the nasopharynx; $\mathbf{H}$ ) Remove the anterolateral and inferior part of sphenoid bone which would damage the pedicle of nasal septal flap when it bulges; I) the flap is located on the defect and spread out. (Ns: nasal septum, MT: middle turbinate, IT: inferior turbinate, C: cutton, S: scissor, Cho: choana, Fp: Flap, P: punch). 
(10) also supported that the reconstruction with pedicled nasal mucosal flap needs a multilayer technique. This study used multilayer reconstruction with pedicled mucosal flap to decrease the incidence of CSF. During follow-up, we found that nasal mucous membrane covered the surgical area, wound healing was good, and thus the surgery achieved good reconstruction for anatomical structure and nasal function.

Luginbuhl et al. (23) put forward the concept of high flow intraoperative CSF leakage (e.g., opening of a cistern or ventricle, or suspected high ventricular pressure). In our 20 patients, the incidence of CSF leakage in the late postoperative period $(3 / 20)$ was $15.0 \%$. We speculate that all patients had high flow intraoperative CSF leakage (20/20). Luginbuhl et al. (23) observed that the incidence of postoperative CSF leakage was $45 \%$ in the patients with high-flow CSF leakage or with large dural defects after surgery. Thus, the incidence
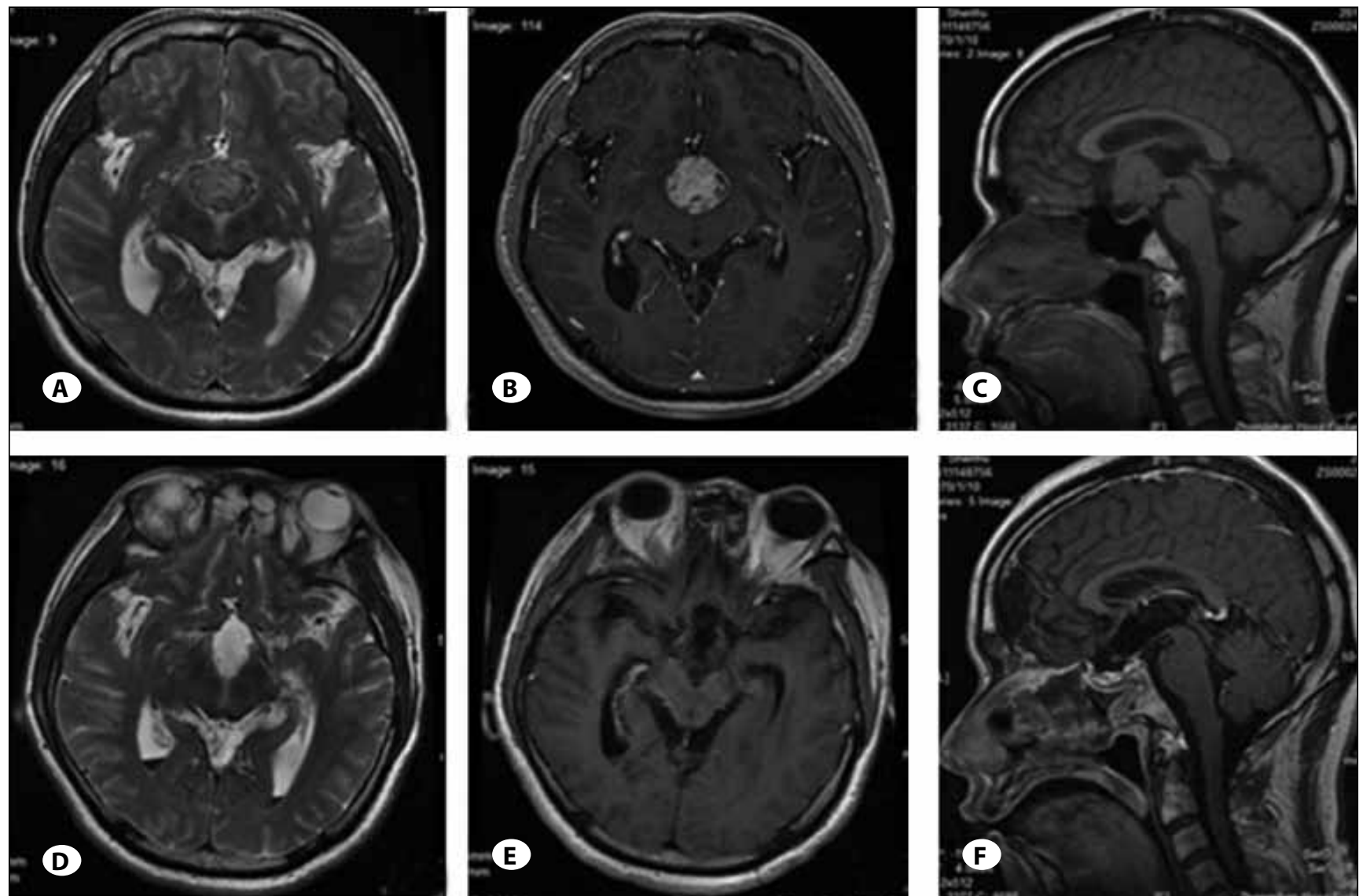

Figure 2: One case with suprasellar craniopharyngioma contrast by preoperative (A, B, C) and postoperative (D, E, and F) MRI scanning, F: tumor is totally resected and mucosal flap reconstruction grows well.
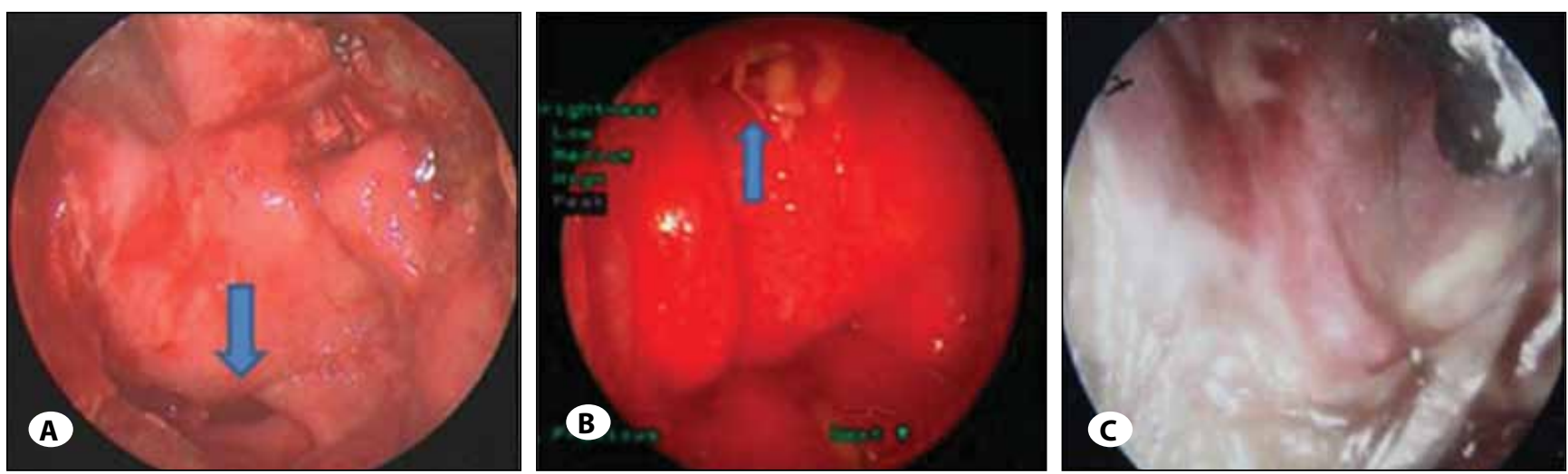

Figure 3: A, B) two patients encountered CSF leakage, arrow points to the fistula; C) endoscopic view of the anterior cranial base 1 month after flap placement, showing a completely mucosalized anterior cranial base. 
of CSF leakage in this study was much lower than the previous report.

Key factors for making a nasal septal mucosal flap include: 1, According to the range to be exposed in surgery; the mucosal flap can be designed by CT or MRI before surgery. Pinheiro-Neto et al. (24) concluded that it is useful to design the pedicled nasoseptal flap for skull base reconstruction by CT study before surgery. During surgery, mucosal flap can be produced under the guidance of navigation. 2, In this case, the right nasal septal mucosal flap was made as the main choice; but we should consider when the nasal septum leaned to one side or one side of the mucosal flap was damaged or invaded by tumor tissue, then the other side of mucosal flap should be considered. 3, While making the mucosal flap, the ipsilateral middle turbinate was cut off to expand the operation field. Hadad et al introduced the relevant content in the literature (14). 4, A stomach tube was placed in the nasopharynx through one side of the nasal cavity to suck the smoke produced by coagulation or blood and water during surgery. 5, In this case, the process of mucosal incision started from the lower cut; otherwise the bleeding from the upper incision would influence the lower part of the operative field. In addition, the mucosa must be cut open to the periosteum, then adhesion will not occur and mucosal flap is easy to peel away from the septal bone without damage. 6, The upper part of the incision was made with a scissor. Considering less thermal injury and protecting the olfactory function, this protocol is different from that of Hadad et al. (14). 7, If a large mucosal flap is required, it can include the nasal floor mucosa. Notice that the intersection of the nose floor and nasal septum adhesions needs to be peeled carefully to prevent mucosal tear injury. 8, The pedicle of flap should be as long as possible, while the lateral wall of sphenoid sinus near the site of vascular pedicle should be removed as much as possible to prevent the pedicled mucosal flap from being extruded by the bone, and to reduce the length to stride over it, so the effective length of mucosal flap is increased and can cover the defect of skull base. 9, During surgery, remember not to damage the mucosal flap.

Key factors for the reconstruction with nasal septal mucosal flap include: 1 , In surgery, make sure that the stuffing is not too tight to affect blood supply, for example, Kassam (17) and Kang (21) suggested that the inflation of the Foley catheter balloon should be observed under endoscope as over inflation can oppress the vascular pedicle and compress intracranial structures; however, the stuffing should not be too loose so as to result in the migration of mucosal flap. Draf et al. (8) found that graft migration usually occurs in the first week after surgery, so they suggested that the key is to ensure that the reconstruction material cannot be offset within a week after reconstruction. 2, Make sure to place the periosteal surface of the flap against denuded walls, and fix tight. 3, The mucosal flap needs to cover the repairing surface smoothly and its edge cannot be curled. 4, Once the mucosal flap was in place, biological glue was used to cover and fix it. Then the gelatin sponge was packed to separate biological glue and supporting materials (such as the balloon). This prevents the supporting materials from contact with biological glue, and avoids damage to the mucosal flap due to adhesion when the supporting materials are removed.

As for the time to remove the supporting materials or external lumbar drainage (ELD): Kassam et al. (17) removed the balloon or packing 3 to 5 days after surgery, but Tachibana et al. (25) demonstrated that a tight connection between the graft and the dura started to form within 1 week after surgery, so the filling of the graft that can further strengthen the reconstruction in conjunction with mucosal growth and the closure needs at least a week, and then the reconstruction is accomplished. Our results are consistent with this inference. So we think the removal of packing, balloon or lumbar puncture should be considered in concrete condition, such as: intraoperative high flow CSF (e.g., opening of a cistern or ventricle, or suspected high ventricular pressure) (23) or not; postoperative CSF or not. Our comments include: 1, Patients without CSF leakage in the intra- and post-operative period do not need lumbar puncture, and the packing is left in place for 3-5 days; Couldwell et al. (5) also suggested that the routine sellar reconstruction or closure after transsphenoidal surgery is unnecessary for those patients without intraoperative CSF leakage. 2, For patients with intraoperative high flow CSF or postoperative CSF leakage, they are mostly led an ELD; for patients without intraoperative high flow CSF leakage but with postoperative CSF leakage, ELD and packing need to be left in place for 2-3 days after CSF leakage is controlled. 3, For patients with both intraoperative and postoperative highflow CSF leakage, ELD are needed and continuous drainage is no less than one week, whether CSF leakage is controlled or not. 4, For patients with intracranial infection, the retention time of ELD can be extended appropriately. In these cases, the longest time was 14 days before the lumbar puncture was excluded. 5, For patients with continuous postoperative CSF leakage for more than a week even after ELD, the reoperation of reconstruction may be considered. Luginbuhl et al. (23) found that patients with intraoperative high-flow CSF leakage but without postoperative CSF leakage, the lumbar puncture was removed at an average of 7 days; but other three cases whose ELD was retained for a mean duration of 11 days needed further surgery. These results correlate well with our study.

In this study, three patients encountered CSF leakage in the early postoperative period and underwent a second surgery. One was hemangioblastoma, and the other two were craniopharyngioma. For the hemangioblastoma patient, the balloon was burst and did not work; and a similar case was reported by Kassam et al. (18). One of the two patients with craniopharyngioma was treated by Gamma Knife. The healing of mucosal flap was poor, and then the patient developed CSF leakage. The other patient with craniopharyngioma was not applied a balloon but replaced with iodoform gauze during surgery, so the reconstruction failed. During the surgical procedure of reconstruction, we found that the ventage was located at the upper left corner in one case, and the 
other one was located at the bottom of the clivus area. So we think CSF leakage was caused by the iodoform gauze. Because the iodoform gauze provides weak support and pressure discontinuity, it results in mucosal flap shrinkage and poor fit. A balloon can fix the mucosal flap tightly and play a supportive role, so it can ensure the success of mucosal flap reconstruction. Thus the proper use of balloon plays an essential role in mucosal flap reconstruction.

In the late postoperative period, two patients encountered CSF leakage. One was craniopharyngioma, and the other was chordoma. Because it's uncomfortable for this craniopharyngioma patient to insert Foley balloon and long balloon catheter remained outside of the nose. Moreover, this patient accidentally pulled out the balloon and then reinserted, so he encountered CSF leakage two month after discharge. The site of CSF leakage was located at the highest area. Further reconstruction surgery was done to control the leakage successfully. Another chordoma patient was treated by Gamma Knife, did not follow recommendations and participated in heavy physical labor. Four month after surgery, this patient developed CSF leakage accompanied with meningitis, then gave up treatment and died.

The upper sella caused by Craniopharyngioma can affect the bottom of the third ventricle, and the incidence of high-flow CSF leakage is high in the intraoperative and postoperative periods so the reconstruction in these patients is especially important. Compared with craniopharyngioma, the incidence of postoperative CSF leakage is low in pituitary tumors, and the effect of reconstruction is relatively good. Even if pituitary tumors cause the upper sella, they are not invasive and saddle diaphragm still exists. All are conducive to fix the reconstruction materials. During the procedure of craniopharyngioma tumor surgery, we should try our best to protect the pituitary stalk and saddle diaphragm, as they are beneficial to support reconstruction. Moreover, it is important to minimize the defect of dura mater and the range of open arachnoid, which is beneficial for reconstruction. In two recent cases, a new gasket sealing technique was used. This technique was applied by Leng et al. in 2007 (22). They created a "gasket seal" by autologous fascia lata around a bone buttress by the application of a tissue sealant such as DuraSeal, and they concluded that it is an effective method for achieving watertight closure of the anterior cranial base after endoscopic intradural surgery. We applied this technique to enforce our nasal mucosal pedicled flap and achieved successful reconstruction.

\section{CONCLUSIONS}

Multilayer reconstruction with a nasal pedicled flap seems to be useful and reliable for ventral skull base defect using the endoscopic endonasal approach. This method has many beneficial effects, including low incidence of postoperative CSF leakage, faster recovery, shorter hospitalization period, complete tissue repair, and long-term effectiveness. Moreover, the application of balloon and ELD plays an important role in the mucosal flap reconstruction.

\section{ACKNOWLEDGEMENT}

This study was not supported by any grant, and we did not have any financial interest in any materials or devices described.

\section{REFERENCES}

1. Caicedo-Granados $\mathrm{E}$, Carrau R, Snyderman $\mathrm{CH}$, Prevedello D, Fernandez-Miranda J, Gardner P, Kassam A: Reverse rotation flap for reconstruction of donor site after vascular pedicled nasoseptal flap in skull base surgery. Laryngoscope 120(8):1550-1552, 2010

2. Carrabba G, Dehdashti AR, Gentili F: Surgery for clival lesions: Open resection versus the expanded endoscopic endonasal approach. Neurosurg Focus 25(6):E7, 2008

3. Cavallo LM, Messina A, Esposito F, de Divitiis O, Dal Fabbro $M$, de Divitiis E, Cappabianca P: Skull base reconstruction in the extended endoscopic transsphenoidal approach for suprasellar lesions. J Neurosurg 107(4):713-720, 2007

4. Ceylan S, Koc K, Anik I: Extended endoscopic approaches for midline skull-base lesions. Neurosurg Rev 32(3):309-319, 2000

5. Couldwell WT, Kan P, Weiss MH: Simple closure following transsphenoidal surgery. Technical note. Neurosurg Focus 20(3):E11, 2006

6. Prevedello DM, Barges-Coll J, Fernandez-Miranda JC, Morera V, Jacobson D, Madhok R, dos Santos MC, Zanation A, Snyderman CH, Gardner P, Kassam AB, Carrau R: Middle Turbinate Flap for Skull Base Reconstruction: Cadaveric Feasibility Study. Laryngoscope 119(11):2094-2098, 2009

7. de Divitiis E, Cappabianca P, Cavallo LM: Endoscopic transsphenoidal approach: Adaptability of the procedure to different sellar lesions. Neurosurgery 51(3):699-705, 2002

8. Draf W, Schick B: How I do it: Endoscopic-microscopic anterior skull base reconstruction. Skull Base 17(1):53-58, 2007

9. El-Banhawy OA, El-Dien Ael-H, Zolfakar AS, Halaka AN, Ayad $\mathrm{H}$ : Endoscopic endonasal partial middle turbinectomy approach: Adaptability of the procedure in a cadaveric study and in surgery for different sphenoid sinus and skull base lesions. Skull Base 16(1):1-13, 2006

10. El-Banhawy OA, Halaka AN, Altuwaijri MA, Ayad H, ElSharnoby MM: Long-term outcome of endonasal endoscopic skull base reconstruction with nasal turbinate graft. Skull Base 18(5):297-308, 2008

11. El-Banhawy OA, Halaka AN, El-Dien AE, Ayad H: Sellar floor reconstruction with nasal turbinate tissue after endoscopic endonasal transsphenoidal surgery for pituitary adenomas. Minim Invasive Neurosurg 46(5):289-292, 2003

12. Fortes FS, Carrau RL, Snyderman $C H$, Prevedello D, Vescan A, Mintz A, Gardner P, Kassam AB: The posterior pedicle inferior turbinate flap: A new vascularized flap for skull base reconstruction. Laryngoscope 117(8):1329-1332, 2007

13. Frank G, Pasquini E, Doglietto F, Mazzatenta D, Sciarretta V, Farneti G, Calbucci F: The endoscopic extended transsphenoidal approach for craniopharyngiomas. Neurosurgery 59(1 Suppl 1):ONS75-83, 2006 
14. Hadad G, Bassagasteguy L, Carrau RL, Mataza JC, Kassam A, Snyderman $\mathrm{CH}$, Mintz A: A novel reconstructive technique after endoscopic expanded endonasal approaches: Vascular pedicle nasoseptal flap. Laryngoscope 116(10):1882-1886, 2006

15. Horiguchi K, Murai $H$, Hasegawa $Y$, Hanazawa T, Yamakami I, Saeki N: Endoscopic endonasal skull base reconstruction using a nasal septal flap: Surgical results and comparison with previous reconstructions. Neurosurg Rev 33(2):235-241, 2010

16. Kassam AB, Gardner P, Snyderman C, Mintz A, Carrau R: Expanded endonasal approach: Fully endoscopic, completely transnasal approach to the middle third of the clivus, petrous bone, middle cranial fossa, and infratemporal fossa. Neurosurg Focus 19(1):E6, 2005

17. Kassam AB, Thomas A, Carrau RL, Snyderman $\mathrm{CH}$, Vescan $A$, Prevedello D, Mintz A, Gardner P: Endoscopic reconstruction of the cranial base using a pedicled nasoseptal flap. Neurosurgery 63(1 Suppl 1):ONS44-52, 2008

18. Kassam A, Carrau RL, Snyderman CH, Gardner P, Mintz A: Evolution of reconstructive techniques following endoscopic expanded endonasal approaches. Neurosurg Focus 19(1):E8, 2005
19. Kassam A, Snyderman CH, Mintz A, Gardner P, Carrau RL: Expanded endonasal approach: The rostrocaudal axis. Part I. Crista galli to the sella turcica. Neurosurg Focus 19(1):E3, 2005

20. Kassam A, Thomas AJ, Snyderman C, Carrau R, Gardner P, Mintz A, Kanaan H, Horowitz M, Pollack IF: Fully endoscopic expanded endonasal approach treating skull base lesions in pediatric patients. J Neurosurg 106(2 Suppl):75-86, 2007

21. Kang MD, Escott E, Thomas AJ, Carrau RL, Snyderman $\mathrm{CH}$, Kassam AB, Rothfus W: The MR imaging appearance of the vascular pedicle nasoseptal flap. AJNR Am J Neuroradiol 30(4):781-786, 2009

22. Leng LZ, Brown S, Anand VK, Schwartz TH: "Gasket-seal" watertight closure in minimal-access endoscopic cranial base surgery. Neurosurgery 62(5 Suppl 2):ONSE342-43, 2008

23. Luginbuhl AJ, Campbell PG, Evans J, Rosen M: Endoscopic repair of high-flow cranial base defects using a bilayer button. Laryngoscope 120(5):876-880, 2010

24. Pinheiro-Neto CD, Prevedello DM, Carrau RL, Snyderman $\mathrm{CH}$, Mintz A, Gardner P, Kassam A: Improving the design of the pedicled nasoseptal flap for skull base reconstruction: $A$ radioanatomic study. Laryngoscope 117(9):1560-1569, 2007

25. Tachibana E, Saito K, Fukuta K, Yoshida J: Evaluation of the healing process after dural reconstruction achieved using a free fascial graft. J Neurosurg 96(2):280-286, 2002 